\title{
Diverse phytoplasmas associated with maize bushy stunt disease in Peru
}

\author{
Delia Gamarra Gamarra • Charo Milagros Villar • Gilberto Torres Suarez • \\ Walter Darlyn Ingaruca Esteban • Nicoletta Contaldo • \\ Emerson Clovis Carrasco Lozano $(\mathbb{D})$ Assunta Bertaccini
}

Accepted: 23 January 2022 / Published online: 5 February 2022

(C) The Author(s) 2022

\begin{abstract}
Corn plants showing symptoms of midribs chlorosis, and leaf reddening, short internodes, ear proliferation, and plant growth reduction were collected in Peru from fields in nine localities in the provinces of Huancayo, Chupaca, and Jauja in the Junín region, and tested to verify phytoplasma presence and identity. Primers amplifying the phytoplasma ribosomal $16 \mathrm{~S}$ and ribosomal protein genes were used. The phytoplasma presence was detected in symptomatic samples from all the surveyed areas. The sequencing of the obtained amplicons indicated the presence of 'Candidatus Phytoplasma asteris' and 'Ca. P. pruni'-related strains. A BLASTn search of sequenced genes showed that the two 'Candidatus Phytoplasma' strains identified in corn shares $100 \%$ and $99.82 \%$ identity with the ' $C a$. $P$. asteris' strains from maize and $99.92 \%$ and $99.55 \%$ with 'Ca. $P$. pruni'-related strains, respectively. The RFLP analyses allowed to enclose these phytoplasma strains in the 16SrI-B and 16SrIII-J subgroups; however, the two phytoplasmas were, in some cases, present in mixed infection. The 16 SrIII-J phytoplasma is for the
\end{abstract}

D. G. Gamarra • C. M. Villar • G. T. Suarez •

W. D. I. Esteban • E. C. C. Lozano $(\bowtie)$

Center for Plant Molecular Biology Research, Universidad

Nacional del Centro del Peru, Av. Mariscal Castilla N 3909, El

Tambo, Huancayo, Peru

e-mail: eccarrascol@unal.edu.co

e-mail: ecarrasco@uncp.edu.pe

N. Contaldo · A. Bertaccini

Department of Agricultural and Food Sciences, Alma Mater

Studiorum - University of Bologna, Viale G. Fanin, 40,

40127 Bologna, Italy first time reported associated with the maize bushy stunt disease and this represent a relevant information for the disease epidemiology towards its appropriate management in the affected area.

Keywords Zea mays Phytoplasma $\cdot$ Shortening of internodes $\cdot$ Disease $\cdot$ Molecular detection

\section{Introduction}

Corn is one of the main species cultivated worldwide (FAO, 2020). In Peru, both hard yellow and starchy corns are grown for human consumption as dry or wet grain (Huamanchumo de la Cuba, 2013). According to the Peruvian Ministry of Agrarian Development and Irrigation, the national production of starchy corn for 2019 was 305,198 tons, (MIDAGRI, 2021). Maize bushy stunt (MBS) is the most important disease that decreases maize production especially in Latin American cultivations, where it can decrease the production and yield of the crop up to $100 \%$ (Jones \& Medina, 2020). The disease has been reported in the United States, Costa Rica (Harrison et al., 1996), Mexico (Pérez-López et al., 2016), Nicaragua (Hruska et al., 1996), Belize (Henríquez et al., 1999), Colombia (Duduk et al., 2008), and Brazil (Bedendo et al., 1997). In Peru, MBS has been reported in the departments of Ancash and Ayacucho (Nault et al., 1979, 1981) and in the Junin region (Hodgetts et al., 2009; Nipah et al., 2007). The MBS infected corn plants shows symptoms of midribs chlorosis, and leaf 
reddening, short internodes, ear proliferation, and plant growth reduction (Bedendo et al., 1997). This disease was reported associated with the presence of 'Candidatus Phytoplasma asteris' (16SrI-B subgroup) (Lee et al., 2004) and known to be transmitted by Dalbulus maidis (Hemiptera: Cicadellidae) (Nault \& Delong, 1980). The complete genome of a Brazilian strain of this phytoplasma from corn was recently sequenced (Orlovskis et al., 2017). Phytoplasmas are pleomorphic bacteria with size ranging from 200 to $800 \mathrm{~nm}$. They multiply and survive in isotonic environments including plant phloem and hemolymph of insect vectors (Bertaccini et al., 2014) and are classified using molecular tools such as nested polymerase chain reaction (PCR) on the $16 \mathrm{~S}$ ribosomal gene followed by sequencing or restriction fragment length polymorphism (RFLP) analyses. The two methods are defining 'Candidatus Phytoplasma' species and 16S ribosomal groups, respectively (Bertaccini \& Lee, 2018; IRPCM, 2004).

Symptoms associated with MBS were observed more than ten years ago in fields located in the Mantaro Valley (Junín region) (Hodgetts et al., 2009). In the last production campaigns these symptoms were again observed in several fields located in the same area. Considering the increasing yield losses, a survey was carried out to verify the symptom incidence and the identity of the associated phytoplasmas to devise the most appropriate management measures to be adopted to reduce the MBS impact in these corn cultivations.

\section{Materials and methods}

Sample collection and disease incidence estimation Whole plants with symptoms of chlorotic streaking, shoot proliferation, anthocyanescence, dwarfism, generalized chlorosis, bud atrophy, and internode shortening (Fig. 1) were collected in the department of Junin-Peru from production fields in the localities of Sicaya, San Agustin de Cajas, Hualhuas, and San Jeronimo located in Huancayo province, Tres de Diciembre, San Juan de Iscos, Ahuac, Chupaca in Chupaca province and El Mantaro in Jauja province (Table 1; Fig. 2), between November 2018 and April 2019. A total of 114 samples from nine different areas were sampled and, after washing under tape water, $2.5 \mathrm{~g}$ of leaf vein tissues were stored at $-20{ }^{\circ} \mathrm{C}$ for nucleic acid extraction. Disease incidence estimation was calculated in each area as the proportion of fields with the number of plants showing MBS symptoms to the total number of fields assessed multiplied by 100 .

Nucleic acid extraction The DNA extraction from the plant samples was done using a CTAB method (Doyle $\&$ Doyle, 1990). For negative control, the DNAs of two symptomless plants collected in asymptomatic fields were extracted. The quality and purity of the extracted DNA were verified in a $1 \%$ agarose gel in 1X TAE buffer (40 mM Tris-Acetate, and $1 \mathrm{mM}$ EDTA at $\mathrm{pH}$ 8.3), stained with ethidium bromide $(10 \mathrm{ng} / \mu \mathrm{l})$ and visualized with a Gel Doc $\mathrm{XR}+$ Gel Documentation System (Bio-Rad Laboratories, Inc.). Quantification was obtained by NanoDrop One (Thermo Scientific ${ }^{\mathrm{TM}}$ ).

Detection of disease-associated pathogens To amplify the phytoplasma 16S rRNA gene, the universal primers P1/P7 (Deng \& Hiruki, 1991; Schneider et al., 1995) were used in PCR followed by nested PCR with P1A/16Sr-SR (Lee et al., 2003, 2006), $3 \mathrm{fwd} / 3 \mathrm{rev}$ (Manimekalai et al., 2010), R16F2n/R2 (Gundersen \& Lee, 1996) and fU5/rU3 (Lorenz et al., 1995) primers. PCR with primers MBSF1/ MBSR1, amplifying an ATP-dependent Zn protease gene of phytoplasmas from corn (Harrison et al., 1996) was also performed. Additionally ribosomal protein (rp) gene primers rpL2F3/ rp(I)R1A specific for phytoplasmas in group 16SrI (amplicon about $1200 \mathrm{bp}$ ), and $\mathrm{rp}(\mathrm{III}) \mathrm{F} 1 /$ rp(III)R1, specifically amplifying about 800 bp of the phytoplasmas enclosed in ribosomal group 16SrIII (Martini et al., 2007) were used for phytoplasma identity confirmation. To verify the possible presence of Spiroplasma kunkelii the primers CSSF1/R1 (Barros et al., 2001) were used.

All PCR reactions were carried out in a $25 \mu \mathrm{L}$ mix consisting of $2 \mu \mathrm{L}$ of each primer $(10 \mu \mathrm{M}), 1 \mu \mathrm{L}$ dNTP mix $(100 \mu \mathrm{M}), 2.5 \mu \mathrm{L}$ buffer $(10 \mathrm{x}), 0.2 \mu \mathrm{L}$ Taq DNA polymerase $(5 \mathrm{U} / \mu \mathrm{L})$ (Invitrogen, USA) and $2 \mu \mathrm{L}$ of diluted DNA (approx. $50 \mathrm{ng}$ ) with the cycling reported in the corresponding literatures. For the nested PCR amplification, the amplicons were diluted 1: 30 with sterile distilled water and $1 \mu \mathrm{L}$ was used as a template. The presence of amplified products was verified in $1 \%$ agarose gel as described above. 
Fig. 1 Zea mays plants with phytoplasma symptoms in production fields in Chupaca: a chlorotic streaking, ear proliferation; b anthocyanescence; c dwarfism, generalized chlorosis; $\mathbf{d}$ sprout atrophy and internode shortening

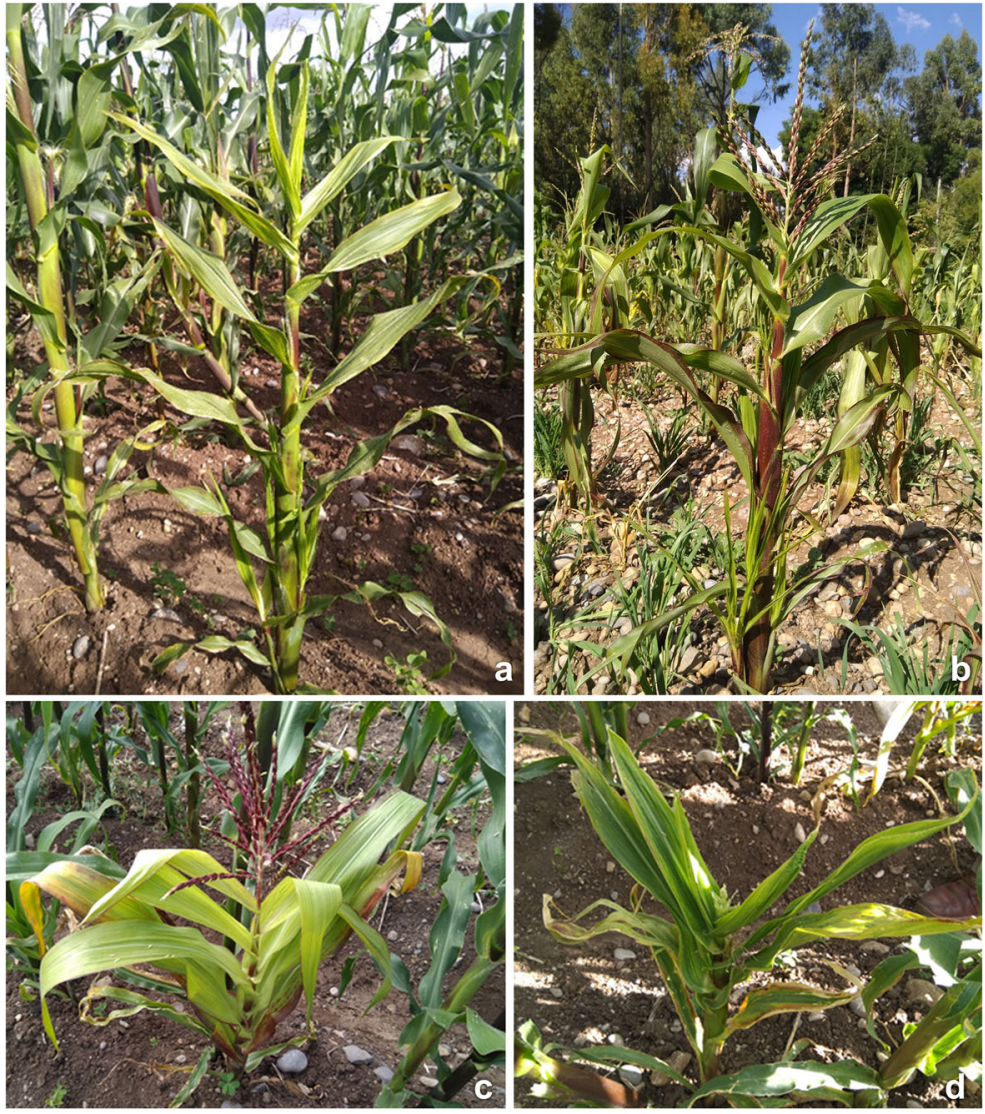

Identification of disease-associated pathogens The $3 \mathrm{fwd} / 3 \mathrm{rev}, \mathrm{R} 16 \mathrm{~F} 2 \mathrm{n} / \mathrm{R} 2$, and fU5/rU3 amplicons were subjected to RFLP analyses using TrulI and/orHhaI (Fermentas, Vilnius, Lithuania) restriction enzymes under the conditions reported by the manufacturer. The obtained restriction profiles were compared with those of 19 phytoplasma strains (Table 2). The reactions were visualized in $6.7 \%$ polyacrylamide gels in $1 \mathrm{X}$ TAE buffer. Virtual restriction profiles were produced for 16S rRNA gene sequences of 1290 and 1248 nucleotides in agarose $4 \%$ gels using pDRAW32 program and in the $i$ PhyClassifier (Zhao et al., 2009) respectively, in both cases the most informative restriction enzymes (Lee et al., 1998) were used for digestion.

Fragments of the phytoplasma 16S ribosomal and $r p$ genes amplified by MBSF1/MBSR1, fU5/rU3, P1A/ 16SrSR, 3fwd/3rev, rpL2F3/rp(I)R1A, rp(III)F1/ rp(III)R1 and CSSF1/R1 primers were purified from agarose gel using the Wizard ${ }^{\circledR}$ SV Gel and PCR Cleaning System Kit (Promega, USA) following the manufacturer's recommendations. The purified fragments from the positive samples for the $16 \mathrm{~S}$ ribosomal gene and $r p$ gene were sequenced in both directions with the same primers used for PCR. The sequences obtained were edited using BioEdit (Hall, 1999), assembled and the sequences analyzed using the Basic Local Alignment Search Tool (BLASTn) (Altschul et al., 1990) by comparing them with those deposited in the National Centre of Biotechnology Information (NCBI) GenBank database (https://www.ncbi.nlm.nih.gov/; Benson et al., 2013). The phytoplasma sequences obtained were deposited at the NCBI GenBank database under the accession numbers MW559787, MW578284, MW 578287, MW578288, MW578363, and MW578290.

Multiple alignments of the consensus sequences were performed using the Cluster W program (Thompson et al., 1994). Phylogenetic analyses were carried out with MEGA v6.0 (Tamura et al., 2013) by the Maximum Likelihood method based on the Kimura 2parameter model (Kimura, 1980) on the 16S rRNA and $r p$ gene sequences. Acholeplasma laidlawii and a ' $C a$. P. trifolii' strain were used as outgroups for the two genes, respectively. 
Table 1 Place of collection of corn samples, symptoms, and results obtained by nested PCR for phytoplasma detection (in bold the samples sequenced and deposited in the GenBank database)

\begin{tabular}{|c|c|c|c|c|}
\hline \multirow[t]{2}{*}{ Sample code } & \multirow[t]{2}{*}{ Collection site } & \multirow[t]{2}{*}{ Symptoms* } & \multicolumn{2}{|c|}{ Detection by PCR } \\
\hline & & & $\begin{array}{l}\text { MBS } \\
\text { F1/ } \\
\text { R1 }\end{array}$ & $\begin{array}{l}\text { Nested } \\
\mathrm{fU} 5 / \\
\mathrm{rU} 3 * *\end{array}$ \\
\hline MSIII2, MSIV1 & Sicaya - Huancayo & Chl. strip., anth. & $2 / 2$ & $1 / 2$ \\
\hline MSI1 & & Chl. strip., anth., poor grains & $0 / 1$ & $1 / 1$ \\
\hline $\begin{array}{l}\text { MSI3, MSI4, MSI6, MSII2, MSII3, } \\
\text { MSIII1, MSIII3, MSI5 }\end{array}$ & & Chl. strip., anth, sh. int., dwarf. & $5 / 8$ & $6 / 8$ \\
\hline MSI2 & & Chl. strip., sh. int., dwarf. & $0 / 1$ & $1 / 1$ \\
\hline MSII1 & & Chl. strip., anth., cob prol. & $0 / 1$ & $1 / 1$ \\
\hline MCI1***, MCI2, MCI3 & San Agustín de Cajas - Huancayo & Anth. & $2 / 3$ & $2 / 3$ \\
\hline MHuIII1, MHuIII2, MHuIII3 & Hualhuas - Huancayo & Anth. & $0 / 3$ & $1 / 3$ \\
\hline MHuII3, MHuII4, MHuII5 & & Anth., cob prol. & $3 / 3$ & $2 / 3$ \\
\hline MHuIII4, MSJIV7 & & Anth., sh. int., dwarf. & $0 / 2$ & $2 / 2$ \\
\hline MHuII1 & & Leaf yellow, anth., sh. int., dwarf. & $1 / 1$ & $1 / 1$ \\
\hline MSJIV2, SJIV3, MSJIV5, MSJIV6, MSJIV8 & San Jerónimo - Huancayo & Anth. & $2 / 5$ & $4 / 5$ \\
\hline $\begin{array}{l}\text { MSJIV4, MSJIV11, MSJIV12***, MSJIV1, } \\
\text { MHuII2, MSJIV9, MSJIV13 }\end{array}$ & & Chl. strip., anth. & $2 / 7$ & $4 / 7$ \\
\hline MSJIV10 & & Chl. strip., anth., sh. int., dwarf. & $0 / 1$ & $1 / 1$ \\
\hline M3DI1, M3DI2, M3DI3, M3DI4 & 3 de Diciembre - Chupaca & Chl. strip., anth., sh. int, dwarf. & $0 / 4$ & $1 / 4$ \\
\hline $\begin{array}{l}\text { MIsI2, MIsI3, MIsI4, MIsI5, MIsI6, MIsI7, } \\
\text { MIsI8, MIsI9, MIsI10, MIsI1 }\end{array}$ & San Juan de Iscos - Chupaca & Chl. strip., anth., sh. int., dwarf. & $1 / 10$ & $5 / 10$ \\
\hline MAII2 & Ahuac - Chupaca & Anth., sh. int., dwarf. & $1 / 1$ & $1 / 1$ \\
\hline MAII1, MAII3, MAII4 & & Chl. strip., anth., sh. int., dwarf. & $3 / 3$ & $3 / 3$ \\
\hline MAII5 & & Chl. strip., sh. int., dwarf. & $1 / 1$ & $1 / 1$ \\
\hline MChII15, MCCIV3 & Chupaca - Chupaca & Chlorotic stretch, sh. int., dwarf. & $2 / 2$ & $2 / 2$ \\
\hline $\begin{array}{l}\text { MCCIV9, MCCIV10, MCCIV11, MCCIV13 } \\
\text { MCCIV14 }\end{array}$ & & $\begin{array}{l}\text { Chlorotic striations, sh. int., dwarf., } \\
\text { cob prol. }\end{array}$ & $5 / 5$ & $5 / 5$ \\
\hline MChI1, MChI2, MChI3, MChI4*** & & Chl. strip., anth., sh. int., dwarf. & $1 / 4$ & $3 / 4$ \\
\hline $\begin{array}{l}\text { MChII14, MCCIII7, MCCIII7.1*** and } \\
\text { MCCIII7.11***, MCCIII7.2, MCCIV2***, } \\
\text { MCCIV4, MCCIV8, MCCV2, MCCV5, } \\
\text { MCCIII4, MCCIII8, MCCV3 }\end{array}$ & & $\begin{array}{l}\text { Chl. strip, proliferation of buds, } \\
\text { sh. int., dwarf., cob prol. }\end{array}$ & $12 / 12$ & $12 / 12$ \\
\hline $\begin{array}{l}\text { MChII1, MChII2, MChII4, MChII5, MChII7, } \\
\text { MChII8, MChII9, MChII10, MChII11, } \\
\text { MChII12, MCCIII1, MCCIII2, MCCIII3, } \\
\text { MCCIII5, MCCIV7, MCCIV15, MCCV6 }\end{array}$ & & Chl. strip, sh. int., dwarf. & $16 / 17$ & $17 / 17$ \\
\hline MCCV1, MCCV4 & & Chl. strip, sh. int., dwarf., cob prol. & $2 / 2$ & $2 / 2$ \\
\hline $\begin{array}{l}\text { MEMI1, MEMI2, MEMI4, MEMI5, MEMI7, } \\
\text { MEMI9, MEMI10, MEMI12, MEMI13, } \\
\text { MEMI14, MEMI15 }\end{array}$ & El Mantaro - Jauja & Anth. & $2 / 11$ & $11 / 11$ \\
\hline MEMI11 & & Anth., sh. int., dwarf. & $0 / 1$ & $1 / 1$ \\
\hline MEMI6 & & Chl. strip., anth. & $0 / 1$ & $1 / 1$ \\
\hline MEMI8 & & Chl. strip., anth., sh. int., dwarf. & $0 / 1$ & $1 / 1$ \\
\hline MEMI3 & & Chl. strip, sh. int., dwarf. & $0 / 1$ & $1 / 1$ \\
\hline
\end{tabular}

\footnotetext{
*, Chl. strip., chlorotic stripping; anth., anthocianescence; sh. int., short internodes; dwarf., dwarfism; cob prol., corn cob proliferation *** nested PCR was carried out on P1/P7, R16F2n/R2 and fU5/rU3 products

***, nested PCR was carried out on P1/P7 and P1A/16Sr-SR products
} 


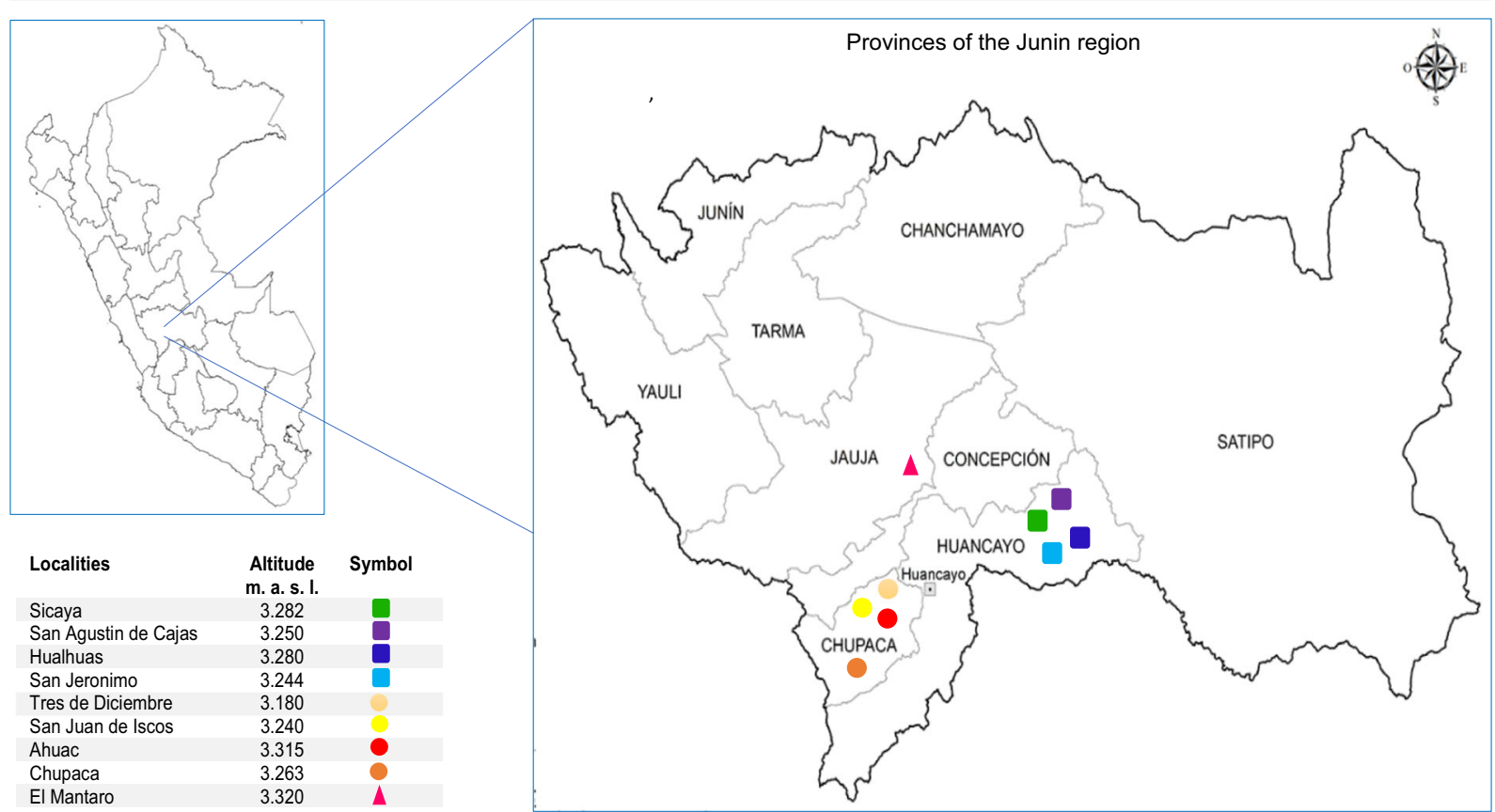

Fig. 2 Sample collection sites in the Junin region, Peru (image modified from https://imagenestotales.com/mapa-del-peru/)

Table 2 Phytoplasma strains used as reference in PCR/RFLP analyses

\begin{tabular}{|c|c|c|c|}
\hline Phytoplasma strain (acronym) & Ribosomal subgroup & Host plant & Literature \\
\hline Aster yellows strain 2192 (AY2192) & 16SrI-B & Periwinkle & Bertaccini, 2014 \\
\hline Potato purple top (PPT) & 16SrI-C & Periwinkle & Bertaccini, 2014 \\
\hline Witches' broom disease of lime (WBDL) & 16SrII-B & Periwinkle & Bertaccini, 2014 \\
\hline Faba bean phyllody (FBC) & 16SrII-C & Periwinkle & Bertaccini, 2014 \\
\hline Peach $\mathrm{X}$ disease $(\mathrm{CX})$ & 16SrIIII-A & Periwinkle & Bertaccini, 2014 \\
\hline Green Valley X disease (GVX) & 16 SrIIII-A & Periwinkle & Bertaccini, 2014 \\
\hline From Euscelidius variegatus (API) & 16SrIIII-B & Periwinkle & Bertaccini, 2014 \\
\hline Crepis biennis yellows (CR) & 16SrIIII-B & Periwinkle & Bertaccini, 2014 \\
\hline Goldenrod yellows (GR) & 16SrIIII-D & Periwinkle & Bertaccini, 2014 \\
\hline Chayote witches' broom (CB7/B7) & 16SrIIII-J & Sechium edule & Montano et al., 2000 \\
\hline Chayote witches' broom (MSCK10) & 16SrIII-J & Momordica charantia & Montano et al., 2000 \\
\hline Pichris echoides yellows (PEY) & 16SrIX-C & Periwinkle & Bertaccini, 2014 \\
\hline Alder yellows (ALY) & $16 \mathrm{SrV}-\mathrm{C}$ & Periwinkle & Bertaccini, 2014 \\
\hline Potato witches' broom (PWB) & 16SrVI-A & Periwinkle & Bertaccini, 2014 \\
\hline Ash yellows (ASHY) & 16SrVII-A & Periwinkle & Bertaccini, 2014 \\
\hline European stone fruit yellows (LNp) & $16 \mathrm{SrX}-\mathrm{B}$ & Periwinkle & Bertaccini, 2014 \\
\hline Flower stunting (BVK) & 16SrXI-C & Periwinkle & Bertaccini, 2014 \\
\hline “"stolbur” (STOL) & 16SrXII-A & Periwinkle & Bertaccini, 2014 \\
\hline Molière disease (MOL) & 16SrXII-A & Periwinkle & Bertaccini, 2014 \\
\hline
\end{tabular}




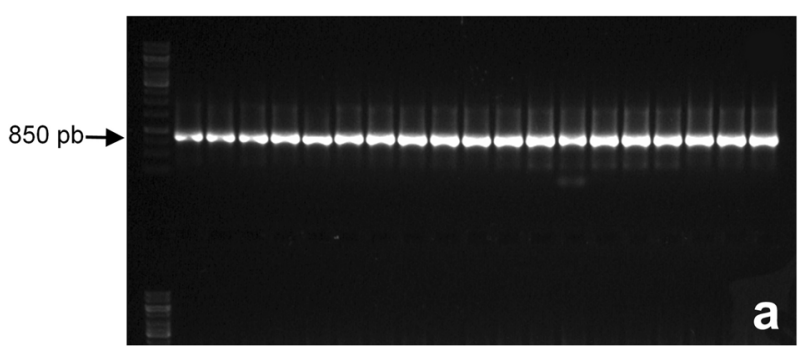

Fig. 3 PCR amplification of phytoplasmas from samples collected at the location of Sicaya: a the $850 \mathrm{bp}$ fragments amplified with primers $\mathrm{fU} 5 / \mathrm{rU} 3$;b the $750 \mathrm{bp}$ fragments amplified with primers

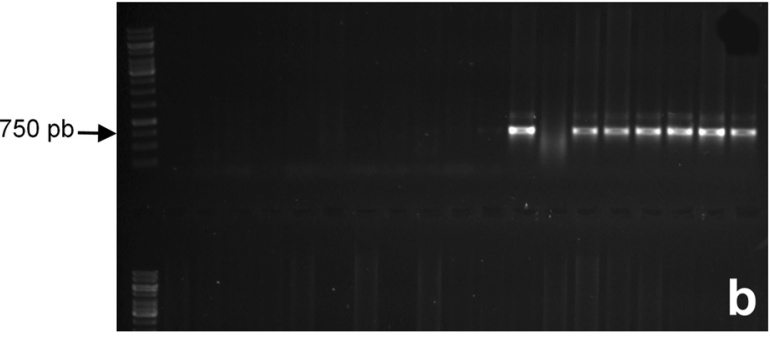

MBSF1/MBSR1. Marker on the left, GeneRuler $1 \mathrm{~kb}$ DNA Ladder (Thermo Scientific ${ }^{\mathrm{TM}}$ )
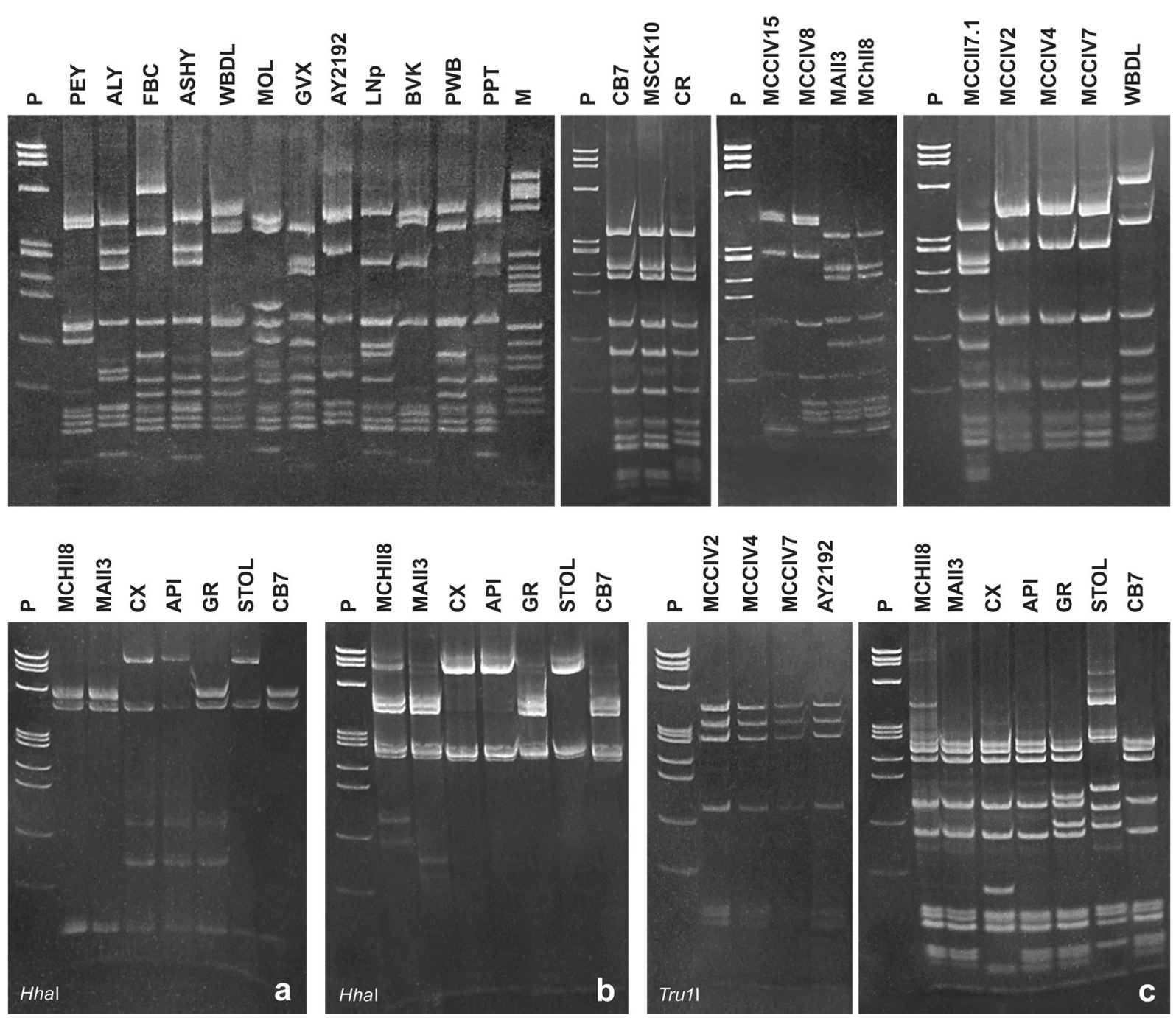

Fig. 4 Phytoplasma RFLP profiles of 16S rDNA in 6.7\% polyacrylamide gels of selected amplicons from DNA samples form corn from Peru (as listed in Table 1) and phytoplasma controls (as listed in Table 2). Top lane: amplicons obtained with the primer pair $3 \mathrm{fwr} / 3 \mathrm{rev}$ (about $1200 \mathrm{nt}$ ) and digested with TrulI. Bottom line: amplicons obtained with primers $3 \mathrm{fwr} / 3 \mathrm{rev}$ in (a) and in (b); c amplicons obtained with primers R16F2n/R2 (1248 nt). Enzymes used are listed at the bottom of each Fig. P, marker phiX174 HaeIII digested with fragment sizes in base pairs from top to bottom of $1353 ; 1078 ; 872 ; 603 ; 310 ; 281 ; 271 ; 234 ; 194 ; 118$ and 72 
Fig. 5 Virtual RFLP analyses with MseI and HhaI of 16Sr RNA gene sequences from corn strains compared with phytoplasmas representing ribosomal subgroups $16 \mathrm{SrIII}$ and $16 \mathrm{SrI}$, respectively. In (a) and (b), the sequence of a 16 SrIII-J strain is compared in agarose $4 \%$ gel using pDraw and in (c) and (b) a sequence of a $16 \mathrm{SrI}-\mathrm{B}$ strain is compared using the $i$ PhyClassifier. $\mathrm{M}$ and MW, PhiX174, marker HaeIII digested
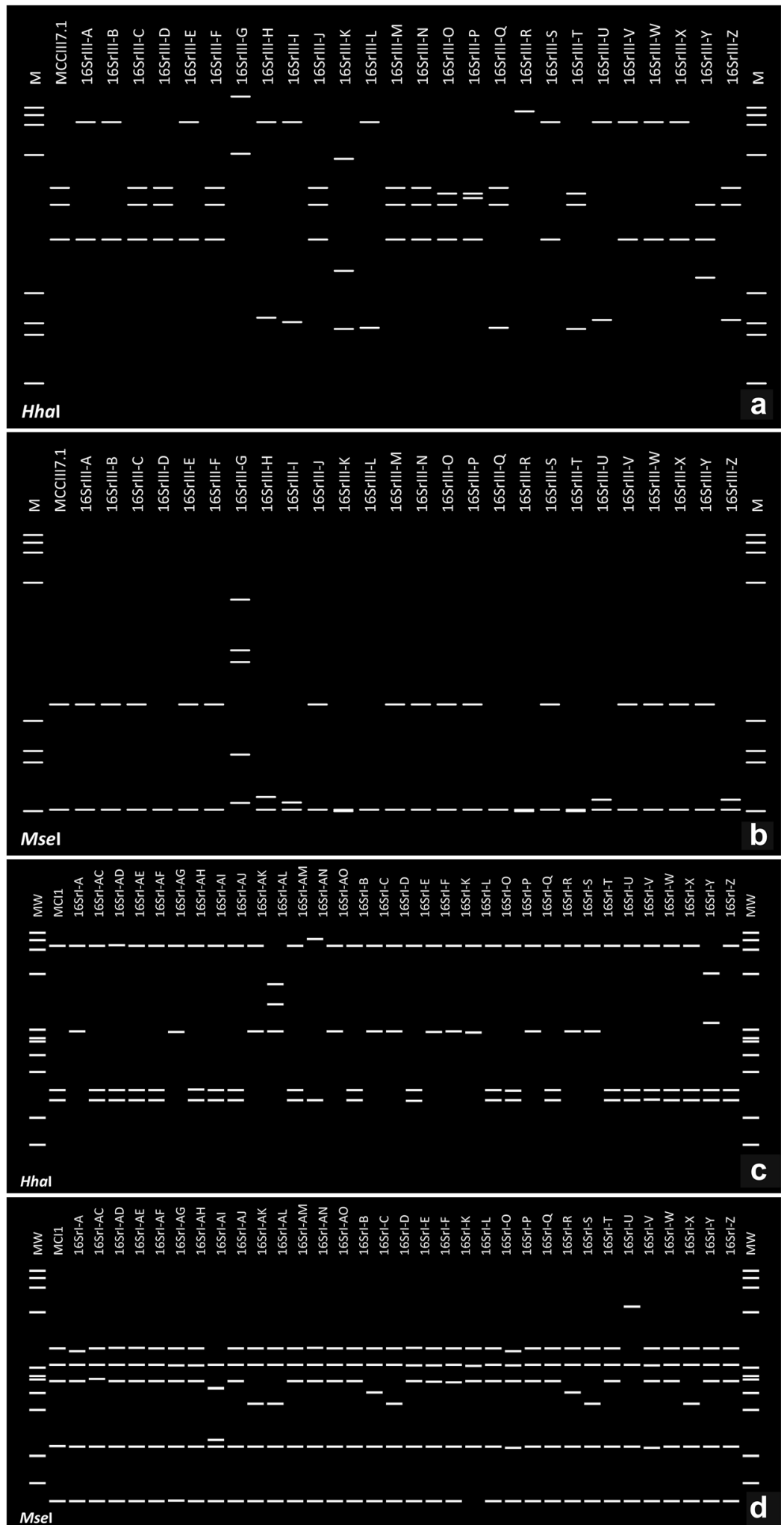


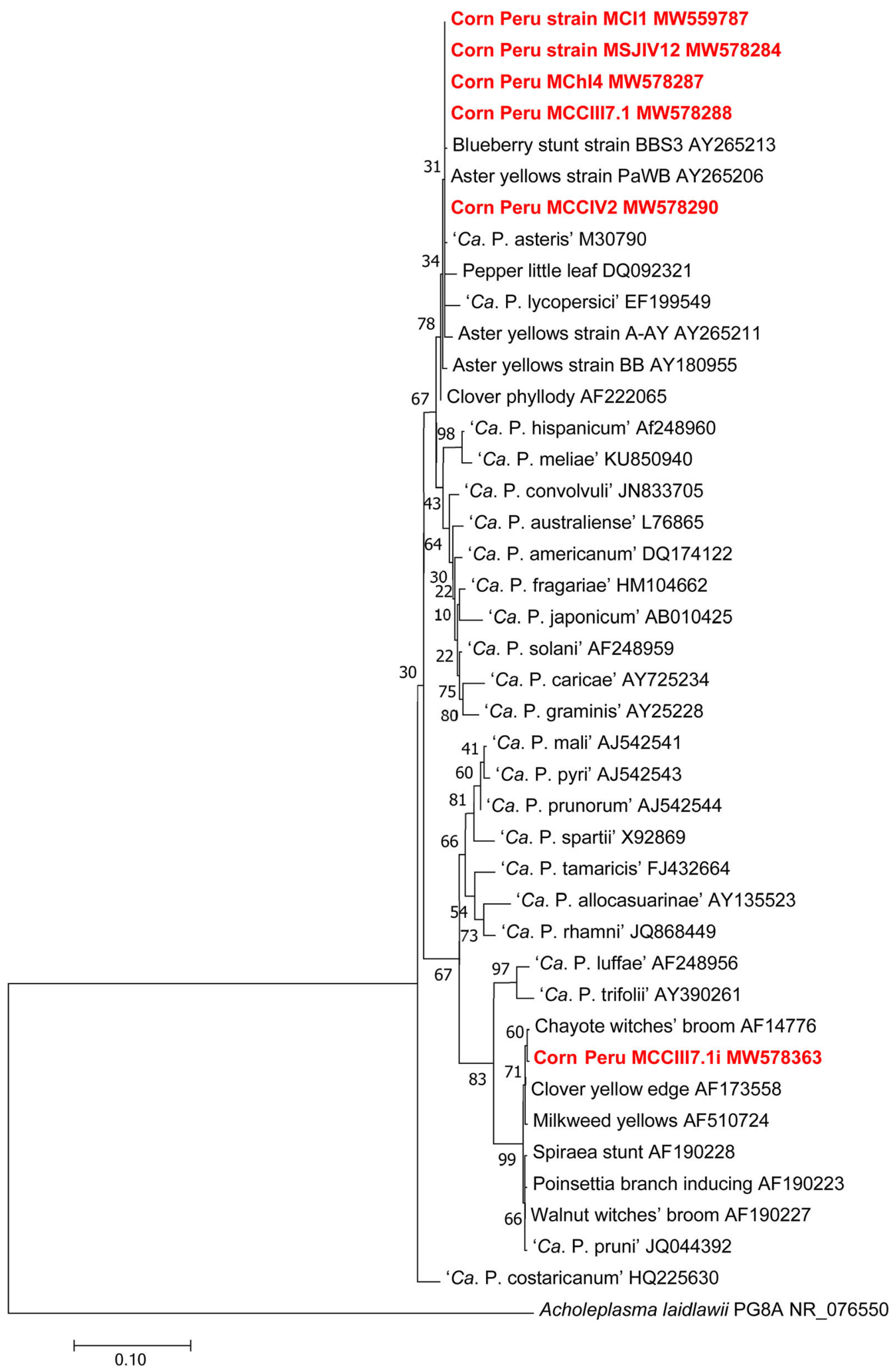


Fig. 6 Molecular analysis by maximum likelihood method of the 16S rRNA gene sequences obtained from the phytoplasmas detected in corn samples from Peru (in bold red). 'Candidatus Phytoplasma' species officially described are used for comparison. Acholeplasma laidlawii is used as an outgroup. The tree with the highest log-likelihood is shown. The percentage of trees in which the associated taxa clustered together is shown next to the branches. The tree is drawn to scale, with branch lengths measured in the number of substitutions per site. Evolutionary analyses were conducted in MEGA6

\section{Results}

The MBS disease incidence was recorded to be $77 \%$ in Sicaya, $66 \%$ in San Agustín de Cajas, $56 \%$ in Hualhuas, $77 \%$ in San Jerónimo, 25\% in Tres de Diciembre, $50 \%$ in San Juan de Iscos, $100 \%$ in Ahuac, $97 \%$ in Chupaca, and $100 \%$ in El Mantaro. A total of 114 plants of Cusqueado variety were collected in the different areas showing symptoms of chlorotic streaking, cob proliferation, anthocyanescence, dwarfism, generalized chlorosis, bud atrophy, and internode shortening (Fig. 1 and Table 1). The nested amplification with fU5/ rU3 primers produced fragments of approximately $850 \mathrm{bp}$ in 94 samples, while the MBSF1/MBSR1 primers amplified fragments of approximately $750 \mathrm{bp}$ in 61 samples (Table 1 and Fig. 3). The use of CSSF1/R1 primers produced in some of the samples amplicons of approximately $700 \mathrm{bp}$, however their sequences resulted aspecific and did not allow to verify the presence of $S$. kunkelii.

Among the 114 samples 15, from different locations, were sent for sequencing using the P1A/ 16SrSR, R16F2n/R2 or $3 \mathrm{fwd} / 3$ rev primers used for their amplification and subjected to RFLP analyses. The RFLP and virtual RFLP analyses of these samples with appropriate restriction enzymes (MseI = TrulI, and HhaI) on the amplicons and the sequences obtained with the phytoplasma primer pairs $\mathrm{R} 16 \mathrm{~F} 2 \mathrm{n} / \mathrm{R} 2$ and $3 \mathrm{fwr} / 3 \mathrm{rev}$, respectively, showed the presence of two profiles and allowed enclosing the detected phytoplasmas in subgroups 16SrI-B and 16SrIII-J (Figs. 4 and 5). A total of five fragments of approximately $1450 \mathrm{bp}$, amplified by nested PCR with primers P1A/16Sr-SR from samples collected in San Agustin de Cajas (MCl1), San Jerónimo (MSJIV12) and Chupaca (MCHI4, MCCIV2, MCCIII7.1) resulted positive to the presence of ' $C a$. $P$. asteris'. Further amplicon sequencing using the same primers of the sample MCCIII7.1 resulted positive to the presence of a 'Ca. P. pruni'-related strain (Fig. 6). Further amplification and sequencing of the 15 selected samples with ribosomal protein group-specific primers confirmed the presence of the two 'Ca. Phytoplasma' species in mixed infection in two surveyed localities (Chupaca and Ahuac Chupaca, Junin). The BLASTn analysis showed that these sequences, except the one submitted to GenBank under the accession number MW578363, had a $100 \%$ identity to those of MBS phytoplasma strains from Colombia, Brazil, and Mexico (GenBank accession numbers HQ530152, CP015149, and AY265208 respectively) and to several other ' $C a$. $P$. asteris'-related strains. The sequence MW578363 showed 99.85\% identity to Solanum lycopersicum phytoplasma clone TomRed (GenBank accession number KC412031) from Argentina and to other phytoplasma strains from Colombia, Bolivia, and Brazil resulting 'Ca. P. pruni'-related and $99.92 \%$ identity to a Delphinium phytoplasma strain (GenBank accession number EF514210).

The BLASTn analysis of ribosomal gene sequences showed $99.82 \%$ and $99.55 \%$ identity to the $r p$ gene from 'Ca. P. asteris' strains from maize from Brazil and oil palm from Colombia (GenBank accession numbers CP015149 and KF434318) and to 'Ca.P. pruni'-related strains from Cucurbita maxima from Argentina (GenBank accession number KC412017), respectively. The dendrogram confirmed that these two 'Candidatus Phytoplasma' strains cluster with phytoplasmas mainly identified in South American areas and belonging to the two identified 'Ca. Phytoplasma' species (Fig. 7).

\section{Discussion}

The molecular testing performed allowed the detection of phytoplasmas in the majority of the symptomatic corn samples collected in the surveyed growing areas of Central Peru (Table 1). The use of U5/U3 primers in nested PCR assays allowed verifying a widespread presence of phytoplasmas in almost all the fields indicating a very close correspondence between symptoms and phytoplasma presence. The two phytoplasmas identified were not differentiated by corn phytoplasma specific primers MBSF1/R1 (Harrison et al., 1996), however 
Fig. 7 Molecular phylogenetic analysis by Maximum Likelihood of the $r p$ gene sequences obtained from phytoplasmas detected in corn from Peru (in bold blue). The strain from corn was compared with the $r p$ gene of strains of ' $\mathrm{Ca}$. $P$. asteris' in a) and of ' $\mathrm{Ca}$. P. pruni' in b). 'Ca. P. trifolii' (16SrVI-A), vinca virescence strain VR, is used as an outgroup. Analyses were conducted in MEGA6

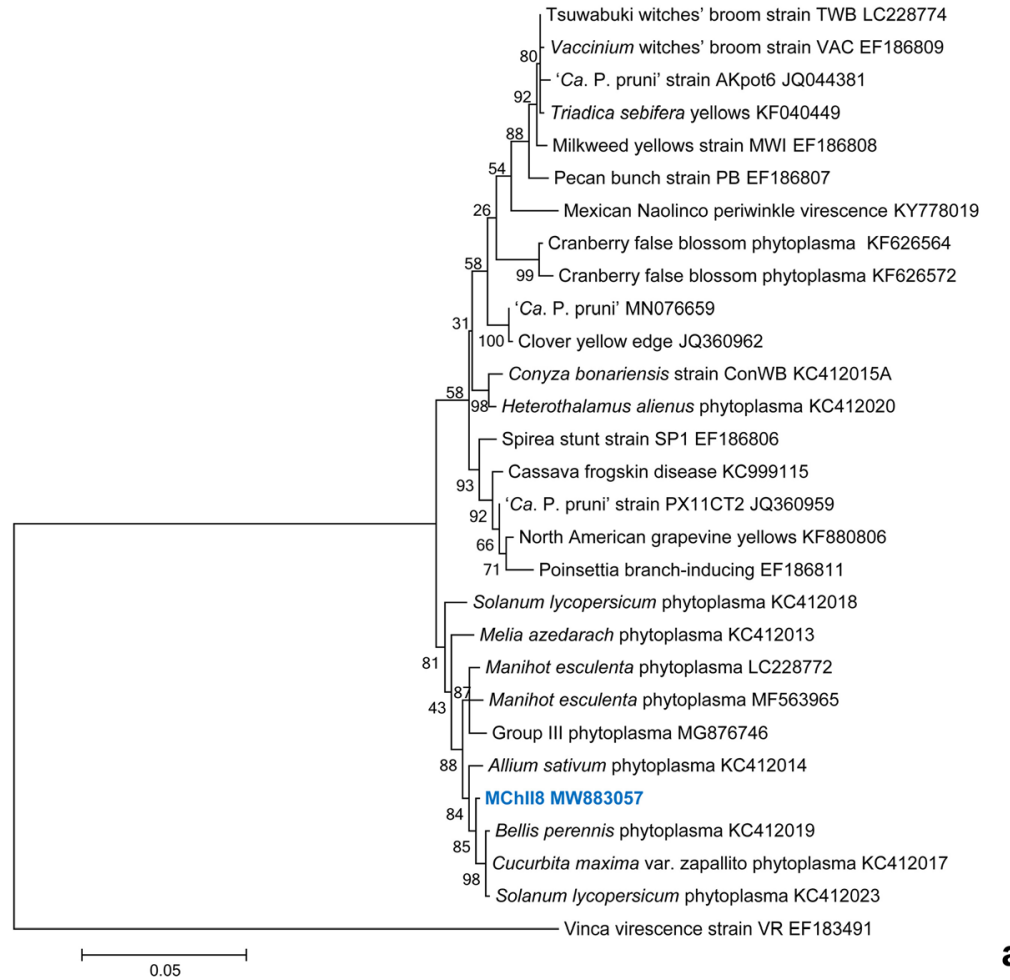

Aster yellows strain AV976 AY264856

Aster yellows strain AV2192 AY183708

Aster yellows Btsv2CarD3 AY183710

Aster yellows strain Btsv2M.f.12 AY183711

Carrot phytoplasma strain ca2006/9 EU215430

Broccoli phytoplasma strain br273 EU215431

Onion proliferation strain OnP2 GU228514

Iranian tomato strain TF2 HQ286478

Sesame phyllody AB741638

Brassica napus strain Brassica 8 KF430808

Canola aster yellows strain NDBN-B KP796186

Oilseed rape strain ny1 KX551965

Rapeseed phyllody strain RP166 CP055264

Lycopersicon esculentum strain DLB1 HQ917034

Nicotiana tabacum yellowing strain DLA1 HQ917033

50. Indian Sesame little BD JQ081306

41. Aster yellows strain AVUT AY264855

Iranian lettuce strain LEY1 HM626106

65 Aster yellows strain Btsv1CarH10 AY183720

Aster yellows strain Btsv2S AY183713

Onion yellows phytoplasma OY-M AP006628

Lettuce yellows strain LY-fjsm1 KP662147

Bitter gourd little leaf AB741632

[ Carrot phytoplasma strain ca2006/5 EU215429

Bougainvillea proliferation strain BuP MN477310

Maize bushy stunt strain MBS AY264858

73

- Conyza bonariensis witches' broom ConWBr MK896924 - Dogfennel yellows DQ321825

53 - Catharanthus roseus aster yellows strain De Villa CP035949

[ Maize bushy stunt strain MBS KF434319

Maize bushy stunt strain M3 CP015149

85 Lethal wilt oil palm strain OP47 KF434318

MCCIV2 MW883058

Aster yellows strain ParsD1 AY183719

Chinaberry witches' broom strain CWB KP662146

- Vinca virescence strain VR EF183491 
RFLP and sequencing of the amplicons obtained with 16S rRNA gene and group specific ribosomal protein primers allowed to confirm the presence of $16 \mathrm{SrI}-\mathrm{B}$ and 16SrIII-J subgroups, in some cases in mixed infection.

The presence of S. kunkelii was not detected in spite of the use of primers reported to be specific (Barros et al., 2001). This pathogen was identified in screening carried out in Mexico and Brazil (Davis et al., 1972; Chen \& Liao, 1975; Gordon et al., 1985; Bedendo et al., 1997) in corn plants showing symptoms very similar to those found in this survey. However, these symptoms are, according to the literature, also associated with the presence of viruses and therefore are not specific and the presence of viruses was not screened since the main focus was the identification of the phytoplasmas that were already reported associated to the disease in this area (Hodgetts et al., 2009).

While the 'Ca. P. asteris' is widely reported to infect corn on the American continent (Lee et al., 2004), this is the first detection of 16 SrIII-J phytoplasmas in corn. The 16SrIII-J phytoplasma strain is widespread in other countries of South America such as Brazil (Montano et al., 2000), Argentina (Galdeano et al., 2013) and Chile (Quiroga et al., 2020) where it was detected in several herbaceous and woody horticultural species. Recently it was also identified in faba bean in Peru (Torres-Suarez et al., 2021) and insect vectors of this phytoplasma strain were identified as Paratanus exitiosus (Beamer) and Bergallia valdiviana Berg 1881 in Chile (Quiroga et al., 2019).

Both phytoplasma strains detected appear to be very closely related to strains detected mainly in Latin America, suggesting a wide distribution of similar strains in different countries and diverse crops. Considering that more than one corn cultivation cycle is performed each year in these areas, it is important to verify insect vectors presence for both phytoplasma strains. Crop rotation and a change in vector feeding preference could also play a relevant role in the infection of the 16SrIII-J phytoplasmas strain in corn. The presence of infected erratic seeds, spouting near the corn fields could maintain and increase the disease dissemination to new crops by insect vectors making very relevant the need of verification of phytoplasma seed transmission reported for corn in other areas of the world (Calari et al., 2011; Satta et al., 2019). The further verification of these epidemiologic aspects will make it possible to develop and apply well focused and environmentally friendly management tools to reduce the epidemic spread of phytoplasmas in corn also in other world cultivations recently reported also in Europe (Çağlar et al., 2019, 2021; Duduk \& Bertaccini, 2006).

Acknowledgments The authors are thankful to the members of the research team of the Center for Plant Molecular Biology Research. Funding: Vice-Rector's Office for Research (CANON Projects, resolution $\mathrm{N}^{\circ}$ 2771-R-2019) of the Universidad Nacional del Centro del Peru.

\section{Declarations}

Research involving human participants and/or animals The authors certify that no special permits were required for the fieldwork investigations. Investigations did not involve any species endangered or protected in Peru.

Informed consent All the authors declare that the principles of ethical and professional conduct were duly followed during the execution of this research. The research was funded by ViceRector's Office for Research (CANON Projects, resolution $\mathrm{N}^{\circ}$ 2771-R-2019) of the Universidad Nacional del Centro del Peru.

Conflict of interest All authors affirm that 1) there exist no actual or potential conflict of interests to disclose, 2) the manuscript is original and has not been published previously (partly or in full), and is not under review for publication elsewhere, 3 ) all the necessary local, national and international standards, regulations and conventions, including normal scientific ethical practices, have been duly followed and respected. Additionally, all authors have endorsed the final version of the manuscript before submission.

Open Access This article is licensed under a Creative Commons Attribution 4.0 International License, which permits use, sharing, adaptation, distribution and reproduction in any medium or format, as long as you give appropriate credit to the original author(s) and the source, provide a link to the Creative Commons licence, and indicate if changes were made. The images or other third party material in this article are included in the article's Creative Commons licence, unless indicated otherwise in a credit line to the material. If material is not included in the article's Creative Commons licence and your intended use is not permitted by statutory regulation or exceeds the permitted use, you will need to obtain permission directly from the copyright holder. To view a copy of this licence, visit http://creativecommons.org/licenses/by/4.0/.

\section{References}

Altschul, S. F., Gish, W., Miller, W., Myers, W., \& Lipman, D. J. (1990). Basic local alignment search tool. Journal of Molecular Biology, 215, 403-410. https://doi.org/10.1016 /S0022-2836(05)80360-2 
Barros, T. S. L., Davis, R. E., Resende, R. O., \& Dally, E. L. (2001). Design of a polymerase chain reaction for specific detection of corn stunt spiroplasma. Plant Disease, 85, 475480. https://doi.org/10.1094/PDIS.2001.85.5.475

Bedendo, I. P., Davis, R. E., \& Dally, E. L. (1997). Molecular evidence for the presence of maize bushy stunt phytoplasma in corn in Brazil. Plant Disease, 81, 957. https://doi. org/10.1094/PDIS.1997.81.8.957C

Benson, D. A., Cavanaugh, M., Clark, K., Karsch-Mizrachi, I., Lipman, D. J., Ostell, J., \& Sayers, E. W. (2013). GenBank. Nucleic Acids Research, 41, D36-D42. https://doi. org/10.1093/nar/gks1195

Bertaccini, A. (2014). Phytoplasma collection. Retrieved June 3, 2021 from http://www.ipwgnet.org/collection.

Bertaccini, A., \& Lee, I.-M. (2018). Phytoplasmas: An update. In G. P. Rao, A. Bertaccini, N. Fiore, \& L. W. Liefting (Eds.), Phytoplasmas: Plant pathogenic Bacteria-I. characterization and epidemiology of Phytoplasma-associated diseases (pp. 1-29). Springer.

Bertaccini, A., Duduk, B., Paltrinieri, S., \& Contaldo, N. (2014). Phytoplasmas and phytoplasma diseases: A severe threat to agriculture. American Journal of Plant Sciences, 5, 17631788. https://doi.org/10.4236/ajps.2014.512191

Çağlar, B. K., Satar, S., Bertaccini, A., \& Elbeaino, T. (2019). Detection and seed transmission of Bermudagrass phytoplasma in maize in Turkey. Journal of Phytopathology, 167(4), 248-255. https://doi.org/10.1111/jph.12792

Çağlar, B. K., Șimşek, E., Dikilitas, M., \& Bertaccini, A. (2021). Characterization of 'Candidatus Phytoplasma solani' associated with a maize leaf reddening disease in Turkey. Journal of Phytopathology, 169(11-12), 658-666. https://doi. org/10.1111/jph.13036

Calari, A., Paltrinieri, S., Contaldo, N., Sakalieva, D., Mori, N., Duduk, B., \& Bertaccini, A. (2011). Molecular evidence of phytoplasmas in winter oilseed rape, tomato, and corn seedlings. Bulletin of Insectology, 64(Supplement), S157-S158.

Chen, T. A., \& Liao, C. H. (1975). Corn stunt spiroplasma: Isolation, cultivation, and proof of pathogenicity. Science, 188, 1015-1017. https://doi.org/10.1126 /science.188.4192.1015

Davis, R. E., Worley, J. F., Whitcomb, R. F., Ishijima, T., \& Steere, R. L. (1972). Helical filaments produced by a mycoplasma-like organism associated with corn stunt disease. Science, 176, 521-523. https://doi.org/10.1126 /science.176.4034.521

Deng, S. J., \& Hiruki, C. (1991). Amplification of 16S ribosomalRNA genes from culturable and nonculturable Mollicutes. Journal of Microbiological Methods, 14, 53-61. https://doi. org/10.1016/0167-7012(91)90007-D

Doyle, J. J., \& Doyle, J. L. (1990). Isolation of plant DNA from fresh tissue. Focus, 12, 13-15.

Duduk, B., \& Bertaccini, A. (2006). Corn with symptoms of reddening: New host of "stolbur" phytoplasma. Plant Disease, 90(10), 1313-1319. https://doi.org/10.1094/PD90-1313

Duduk, B., Mejia, J. F., Paltrinieri, S., Contaldo, N., Alvarez, E., Varón, F., \& Bertaccini, A. (2008). Molecular differentiation of phytoplasmas affecting corn in Colombia and Serbia. In CDrom: II Taller Internacional de Fitoplasmas, La Habana, Cuba.
FAO. (2020). FAOSTAT, production. Retrieved August, 17, 2020 from http://www.fao.org/faostat/en/\#data/QC.

Galdeano, E., Guzmán, F. A., Fernández, F. D., \& Conci, L. R. (2013). Genetic diversity of 16SrIII group phytoplasmas in Argentina. Predominance of subgroups 16SrIII-J and -B and two new subgroups $16 \mathrm{SrIII-W}$ and -X. European Journal of Plant Pathology, 137, 753-764. https://doi.org/10.1007 /s10658-013-0285-5

Gordon, D. T., Nault, L. R., Gordon, N. H., \& Heady, S. E. (1985). Serological detection of corn stunt spiroplasma and maize rayado fino virus in field-collectedDalbulus spp. from Mexico. Plant Disease, 69, 108-111. https://doi. org/10.1094/PD-69-108

Gundersen, D. E., \& Lee, I.-M. (1996). Ultrasensitive detection of phytoplasmas by nested-PCR assays using two universal primer pairs. Phytopathologia Mediterranea, 35, 114-151.

Hall, T. A. (1999). BioEdit: A user-friendly biological sequence alignment editor and analysis program for window 95/98/ NT. Nucleic Acids Symposium Series, 41, 95-98.

Harrison, N. A., Richardson, P. A., Tsai, J. H., Ebbert, M. A., \& Kramer, J. B. (1996). PCR assay for detection of the phytoplasma associated with maize bushy stunt disease. Plant Disease, 80, 263-269. https://doi.org/10.1094/PD-80-0263

Henríquez, N. P., Kenyon, L., \& Quiroz, L. (1999). Corn stunt complex Mollicutes in Belize. Plant Disease, 83, 77. https://doi.org/10.1094/PDIS.1999.83.1.77B

Hodgetts, J., Chuquillangui, C., Muller, G., Arocha, Y., Gamarra, D., Pinillos, O., Velit, E., Lozada, P., Boa, E., Boonham, N., Mumford, R., Barker, I., \& Dickinson, M. (2009). Surveys reveal the occurrence of phytoplasmas in plants at different geographical locations in Peru. Annals of Applied Biology, 155, 15-27. https://doi.org/10.1111/j.17447348.2009.00316.x

Hruska, A. J., Gladstone, S. H., \& Obando, R. (1996). Epidemic roller coaster: Maize stunt disease in Nicaragua. American Entomology, 42, 248-252.

Huamanchumo de la Cuba C. (2013). La cadena de valor de maíz en el Perú. Diagnóstico del estado actual, tendencias y perspectivas. Instituto Interamericano de Cooperación para la Agricultura (IICA), $14 \mathrm{pp}$.

IRPCM. (2004). 'Candidatus Phytoplasma', a taxon for the wallless, non-helical prokaryotes that colonize plant phloem and insects. International Journal of Systematic and Evolutionary Microbiology, 54, 1243-1255. https://doi. org/10.1099/ijs.0.02854-0

Jones, T.-K. L., \& Medina, R. F. (2020). Corn stunt disease: an ideal insect-microbial-plant pathosystem for comprehensive studies of vector-borne plant diseases of corn. Plants, 9, 747762. https://doi.org/10.3390/plants9060747

Kimura, M. (1980). A simple method for estimating evolutionary rate of base substitutions through comparative studies of nucleotide sequences. Journal of Molecular Evolution, 16, 111-120. https://doi.org/10.1007/BF01731581

Lee, I. M., Gundersen-Rindal, D. E., Davis, R. E., \& Bartoszyk, I. M. (1998). Revised classification scheme of phytoplasmas based on RFLP analyses of 16S rRNA and ribosomal protein gene sequences. International Journal of Systematic and Evolutionary Microbiology, 48(4), 1153-1169. https://oi. org/10.1099/00207713-48-4-1153

Lee, I.-M., Martini, M., Bottner, K. D., Dane, R. A., Black, M. C., \& Troxclair, N. (2003). Ecological implications from a 
molecular analysis of phytoplasmas involved in an aster yellows epidemic in various crops in Texas. Phytopathology, 93, 1368-1377.

Lee, I.-M., Gundersen-Rindal, D. E., Davis, R. E., Bottner, K. D., Marcone, C., \& Seemüller, E. (2004). 'Candidatus Phytoplasma asteris', a novel phytoplasma taxon associated with aster yellows and related diseases. International Journal of Systematic and Evolutionary Microbiology, 54, 10371048. https://doi.org/10.1099/ijs.0.02843-0

Lee, I.-M., Zhao, Y., \& Bottner, K. D. (2006). SecY gene sequence analysis for finer differentiation of diverse strains in the aster yellows phytoplasma group. Molecular and Cellular Probes, 20, 87-91. https://doi.org/10.1016/j.mcp.2005.10.001

Lorenz, K.-H., Schneider, B., Ahrens, U., \& Seemüller, E. (1995). Detection of the apple proliferation and pear decline phytoplasmas by PCR amplification of ribosomal and nonribosomal DNA. Phytopathology, 85, 771-776. https://doi.org/10.1094/Phyto-85-771

Manimekalai, R., Soumya, V. P., Sathish Kumar, R., Selvarajan, R., Reddy, K., Thomas, G. V., Sasikala, M., Rajeev, G., \& Baranwal, V. K. (2010). Molecular detection of $16 \mathrm{SrXI}$ group phytoplasma associated with root (wilt) disease of coconut (Cocos nucifera) in India. Plant Disease, 94, 636. https://doi.org/10.1094/PDIS-94-5-0636B

Martini, M., Lee, I.-M., Bottner, K. D., Zhao, Y., Botti, S., Bertaccini, A., Harrison, N. A., Carraro, L., Marcone, C., Khan, A. J., \& Osler, R. (2007). Ribosomal protein genebased phylogeny for finer differentiation and classification of phytoplasmas. International Journal of Systematic and Evolutionary Microbiology, 57, 2037-2051. https://doi. org/10.1099/ijs.0.65013-0

MIDAGRI, (2021). Ministerio de Desarrollo Agrario y Riego. Anuario Estadístico de Producción Agrícola. Retrieved December 17, 2021 from https://siea.midagri.gob. $\mathrm{pe} / \mathrm{p}$ or t a $1 / \mathrm{pub} 1$ i c a c i o n e s/dat o s estadisticas/anuarios/category/26-produccion-agricola

Montano, H. G., Davis, R. E., Dally, E. L., Pimentel, J. P., \& Brioso, P. S. T. (2000). Identification and phylogenetic analysis of a new phytoplasma from diseased chayote in Brazil. Plant Disease, 84, 429-436. https://doi.org/10.1094 /PDIS.2000.84.4.429

Nault, L. R., \& Delong, D. M. (1980). Evidence for co-evolution of leafhoppers in the genus Dalbulus (Cicadellidae: Homoptera) with maize and its ancestors. Annals of Entomological Society of America, 73, 349-353. https://doi. org/10.1093/aesa/73.4.349

Nault, L. R., Gordon, D. T., Gingery, R. E., Bradfute, O. E., \& Loayza, J. C. (1979). Identification of maize viruses and mollicutes and their potential insect vectors in Peru. Phytopathology, 69, 824-828. https://doi.org/10.1094 /Phyto-69-824

Nault, L. R., Gordon, D. T., \& Loayza, J. C. (1981). Maize virus and mycoplasma diseases in Peru. Tropical Pest Management, 27, 363-369. https://doi.org/10.1080 /09670878109413806

Nipah, J. O., Jones, P., Hodgetts, J., \& Dickinson, M. (2007). Detection of phytoplasma DNA in embryos from coconut palms in Ghana, and kernels from maize in Peru. Bulletin of Insectology, 60, 385-386.
Orlovskis, Z., Canale, M. C., Haryono, M., Lopes, J. R. S., Kuo, C. H., \& Hogenhout, S. A. (2017). A few sequence polymorphisms among isolates of maize bushy stunt phytoplasma associate with organ proliferation symptoms of infected maize plants. Annals of Botany, 119, 869-884. https://doi. org/10.1093/aob/mcw213

Pérez-López, E., Olivier, C. Y., Luna-Rodríguez, M., Rodríguez, Y., Iglesias, L. G., Castro-Luna, A., Adame-García, J., \& Dumonceaux, T. J. (2016). Maize bushy stunt phytoplasma affects native corn at high elevations in Southeast Mexico. European Journal of Plant Pathology, 145, 963-971. https://doi.org/10.1007/s10658-016-0883-0

Quiroga, N., Longone, V., González, X., Zamorano, A., Pino, A. M., Picciau, L., Alma, A., Paltrinieri, S., Contaldo, N., Bertaccini, A., \& Fiore, N. (2019). Transmission of 16SrIIIJ phytoplasmas by Paratanus exitiosus (beamer) and Bergallia valdiviana berg 1881 leafhoppers. Phytopathologia Mediterranea, 58, 231-237. https://doi. org/10.14601/Phytopathol_Mediter-1061

Quiroga, N., Gamboa, C., Soto, D., Pino, A. M., Zamorano, A., Campodonico, J., Alma, A., Bertaccini, A., \& Fiore, N. (2020). Update and new epidemiological aspects about grapevine yellows in Chile. Pathogens, 9, 933. https://doi. org/10.3390/pathogens 9110933

Satta, E., Paltrinieri, S., \& Bertaccini, A. (2019). Phytoplasma transmission by seed. In A. Bertaccini, P. G. Weintraub, G. P. Rao, \& N. Mori (Eds.), Phytoplasmas: Plant Pathogenic Bacteria-II. Transmission and Management of Phytoplasma Associated Diseases (pp. 131-147). Springer.

Schneider, B., Seemüller, E., Smart, C. D., \& Kirkpatrick, B. C. (1995). Phylogenetic classification of plant pathogenic mycoplasmalike organisms or phytoplasmas. In S. Razin \& J. G. Tully (Eds.), Molecular and diagnostic procedures in mycoplasmology (pp. 369-380). Academic Press.

Tamura, K., Peterson, D., Stecher, G., Filipski, A., \& Kumar, S. (2013). MEGA6: Molecular evolutionary genetics analysis version 6.0. Molecular Biology and Evolution, 30, 27252729. https://doi.org/10.1093/molbev/mst197

Thompson, J. D., Higgins, D. G., \& Gibson, T. J. (1994). CLUSTALW: Improving the sensitivity of progressive multiple sequence alignment through sequence weighting, position-specific gap penalties and weight matrix choice. Nucleic Acids Research, 22, 4673-4680. https://doi. org/10.1093/nar/22.22.4673

Torres-Suarez, G., Gamarra-Gamarra, D., Villar, C. M., LlaczaMunive, S. L., Satta, E., Carrasco-Lozano, E. C., \& Bertaccini, A. (2021). Detection and identification of a 16SrIII-J subgroup phytoplasma associated with faba bean in Peru. Journal of Phytopathology, 169, 203-208. https://doi.org/10.1111/jph.12977

Zhao, Y., Wei, W., Lee, I.-M., Shao, J., Suo, X., \& Davis, R. E. (2009). Construction of an interactive online phytoplasma classification tool, iPhyClassifier, and its application in analysis of the peach X-disease phytoplasma group (16SrIII). International Journal of Systematic and Evolutionary Microbiology, 59, 2582-2593. https://doi.org/10.1099 /ijs.0.010249-0 